\title{
INTRODUCTION TO `RASASHAASTRA`- THE IATROCHEMISTRY OF AYURVEDA
}

\author{
S. S. Savrikar* and B. Ravishankar** \\ *Vice-Chancellor (Ex)- Gujarat Ayurved University, Professor and Head, Department of \\ Rasashastra, RA Podar Ayurvedic Medical College, Worli Mumbai, India, **Head, \\ Pharmacology Laboratory, Institute of PG Teaching and Research in Ayurveda, Gujarat \\ Ayruved University, Jamnagar- 361 008, India, **Present Address: Director, SDM centre for \\ Research in Ayurveda and Allied Sciences; Udupi- 574 118. Karnataka- India. \\ **E-mail: gravishankar2000@yahoo.com
}

\begin{abstract}
The word Rasashaastra literally means the "Science of Mercury". It is a specialized branch of Ayurveda dealing mainly with materials which are known as 'Rasa dravyaas'. The products dealt under this discipline are an important component of Ayurvedic therapeutics. Considering the importance of this discipline in Ayurvedic therapeutics and the fact that there is dearth of comprehensive review on the subject an attempt has been made in this review to provide a brief but all encompassing coverage of different aspects related to it. The subjects covered in the review are : historical background of the evolvement of Rasashaastra as a specialized branch during different time periods; different aspects of classification 'Rasa dravyaas'; processing of metal and mineral products with a note on the methods used during different time periods; information about methods of pre and post preparation procedures for different kinds of 'Rasa dravyaas'; importance of mercury in Ayurveda, its processing methods and different preparations along with therapeutic indications. In addition attempt has been made to provide basic information on the metal and mineral based preparations mentioned in Ayurvedic Formulary of India; recent development in the field of Rasashaastra and future requirements for the proper development of the discipline. The main focus is to familiarize the readers, from non-ayurvedic background, on different aspects of this specialized discipline.
\end{abstract}

Key words: Rasashaastra, Rasa dravyaas, Traditional systems of medicine ,Mineral and metal based formulations Ayurvedic formulations, Iatrochemistry of Ayurveda

\section{Introduction to 'Rasashaastra'- the Iatrochemistry of Ayurveda}

Pharmacopoeia of 'Ayurveda' comprises of drugs derived not only from herbs but also from minerals, metals and animal products. According to the principles of 'Ayurveda', there is not a single substance in the Universe which does not have a potential to be used as a drug, provided it is used judiciously by the physician where it is required. In this reference Caraka- one of the foremost figures of Ayurveda says

"Anenopadeshen Na Anaushadhibhootam Jagati Kincit dravyam upalabhyate.

Taam Taam Yuktimartham Ca Tam Tamaabhipretya

(Caraka Samhita 1984a - Caraka Sutra 26/12)

According to the source of origin, the substances in the Universe are classified as 'Jangama' i.e. animal sourced e.g. milk, meat, blood, urine etc, 'Audbhida' i.e. plant sourced e.g. leaves, root, stem etc., and 'Paarthiwa' or 'Khanija' i.e. mineral sourced e.g. gold, silver, copper, sulphur etc. (Sushruta Samhitaa 1992a -Susruta Sutra 1/32 and Caraka Samhitaa 1984b- Caraka Sutra 1/68).)

\section{Historical background}

The word Rasashaastra literally means the "Science of Mercury". However, it is a specialized branch of Ayurveda dealing mainly with materials which are known as 'Rasa dravyaas'. They have the following three characteristic attributes: instant effectiveness, requirement of very small doses and extensive therapeutic utility irrespective of constitutional variation. The following Sloka (verses normally in two lines) describes the above given attributes of rasa. 


\section{Savrikar and Afr J Tradit Complement Altern Med. (2011) 8(S):66-82}

“Alpamaatropayogitwaat Arucera Aprasangataha. Kshipram Aarogyadaayitwat Aushadhyebhyo Adhiko Rasaha" (Vaagbhata, Rasaratnasamuccaya,- 28/1, 1976 a)

History of Ayurveda can be divided into three distinct periods depending on the predominance of particular system of management of health and disease. These periods are Vaidika period, Samhitaa period and Post-samhitaa period. The post-samhitaa period is dominated by the renowned alchemist Siddha Naagaarjuna.

Vaidika period is the period of four Vedas - 'Rigveda', 'Yajurveda', 'Saamaveda' and 'Atharvaveda'. 'Atharvaveda', of which 'Ayurveda' forms a substantial part, dates back to 5000 B.C. In the Vaidika era emphasis was given on strengthening and maintenance of the health through management of healthy life style. The object of this system was to facilitate smooth passage of an individual towards 'Moksha', the ultimate salvation. The era of 'Samhitaas' is recognized by the works of great scholars and seers of 'Ayurveda' like 'Maharshi Atreya' and his disciples 'Agnivesha', 'Bhela', 'Jatukarna' etc. These scholars although stressed the importance of maintenance of health like their predecessors, also expanded their vision to pharmacotherapeutics. The therapeutic properties of plants, animal products and minerals were extensively described in their works. In therapeutics, emphasis was given on the use of medicinal plants, being more familiar and assimilable in the human body. Minerals were used, but their use was very much limited compared to the use of plants. Most of the times the minerals were used in combination with plants (herbo-mineral drugs) but use of independent mineral drugs was also not uncommon. The minerals were subjected to intensive processing for giving them a form of drug.

The evolvement of Rasashaastra as a specialized branch is traced to the great Buddhist Sage Naagaarjuna. Who is considered as 'Father of Rasashaastra'. It is believed to have come into its proper existence with its scientific classification and documentation around $8^{\text {th }}$ century. Naagaarjuna proclaimed "Siddhe Rase Karishyaami Nirdaridryamidam jagat" - meaning that I am experimenting with the mercury to eliminate poverty from this world. The main foundation being the concept that the objective of the science of mercury is not limited to Alchemy (Dhaatuvaada) but also to maintain health and strengthen the body for achieving Mukti i.e. ultimate salvation- the concept is incorporated in the sloka as :

"Na Ca Rasashaastram Dhaatuvaadaartham Iti Mantavyam, Dehavedhadvaaraa Muktirev Paramaprayojanaat. " (Anonymous -2004).

Naagaarjuna is also known for his extraordinary acumen in processing mercury with respect to its alchemic and therapeutic use. With the advent of Mercury, a miracle substance in those days, a new class of drugs termed as 'Rasaushadhi' with a new science termed as 'Rasashaastra' appeared on the horizon of 'Ayurvedic system of medicine'. 'Rasashaastra' can be defined as a science of study of mineral and metallic substances with respect to their therapeutic utility including processing of these substances to prepare a drug. In today's scientific parlance 'Rasashaastra' can be equated with 'Iatrochemistry'. Although 'Rasashastra' deals with therapeutic processing and use of all minerals and metals, the study is dominated by knowledge about mercury and techniques of its processing. The science is named after mercury - 'Rasa' being a synonym of 'Mercury'. Physicians using 'Rasaushadhi' in the management of disease are known as 'Rasa-vaidya'. Rasa-vaidyas were supposed to be superior to their professional counterparts using surgical procedures and plants drugs for treating diseases.

RasaVaidyah Smrito Devo Maanusho Moolikaadibhihi.

Adhamaha Shastrdhaabhyaamitthaam Vaidyastridhaa Mataha

(Ayurved Prakash- (Madhava- 1986).

\section{Classification of 'Rasaushadhis'}

The mineral and metallic substances used in Ayurvedic drugs are classified in different ways. Although there is a variation in pattern of classification as well as inclusion of a particular mineral or metal in a particular class, a common theme of classification emerges out from the classics. Generally these drugs are classified in to four distinct classes named- Rasa, Dhaatu, Ratna and Visha. This classification does not have a common distinguishing feature. The class of 'Rasa' is predominantly possessing 'Rasaayana' (adaptogenic effect) effect. Dhaatus are grouped together on account of their capacity to provide structural strength to the body. The minerals possessing gem quality are grouped as Ratna, whereas inherently highly poisonous plants are grouped as Visha. This theme is described in table -1 .

\section{Processing of metal and mineral products}

It was observed by the earlier scholars that in case of animal and plant products, little or no processing was required to put them to use as a drug. Although few drugs like medicated oils, fermented products, prepared from plant and animal products may require little more complex and extensive processes. Many of them could be 


\section{Savrikar and Afr J Tradit Complement Altern Med. (2011) 8(S):66-82}

consumed in their natural form. The minerals as compared to animal and plant products were not compatible with human body constitution. They could not be consumed in their natural form. The belief that intensive and elaborate processing is required to make them fit for therapeutic utilization lead to the evolvement of sophisticated processing procedures.

A distinct principle of producing a drug, compatible with human body, is observed in the processing of mineral substances. The mineral or metallic material is treated with plant or animal substances, compatible with the body. In certain cases substances non-compatible with the human body such as minerals like orpiment (Haitaal), Realgar (Manshila) are also used in processing. However in such cases the ultimate object of the processing is to produce an assimilable product for the human body, without producing harm in therapeutically effective dose.

This treatment makes the processed material compatible and facilitates its easy assimilation. The first obstacle in consumption of mineral material by the humans is its non-edibility due to its hard consistency. Hence the mineral material is vigorously processed to make it physically soft, edible and assimilable. Apart from this, the material is also processed to make it harmless to the body, in other words, to make it free from toxicity in therapeutic doses.

The therapeutic properties of metals like the Gold, Silver, Copper, Iron, Lead and Tin and alloy Bronze (Bell metal) are described by Susrutaacarya ( Sushruta Samhitaa 1992b- Susruta Sutra 46/326-330). Although the mineral and metallic formulations are described in the classics belonging to 'Samhitaa' and 'Post-samhitaa' period, the processing technique of these materials in these periods differs considerably.

\section{Processing of minerals and metals in Samhitaa period:}

The processing of metals for their use in therapeutic formulations is very well described by 'Caraka' with reference to preparation of 'Lohaadi Rasaayana' and by 'Susruta' with reference to 'Ayaskruti'. The first step of preparation of both these formulations involves the process of conversion of metal sheet into a fine powder.

\section{Method of Preparation of Lohaadi rasaayana: (Caraka Samhitaa-1984c- Caraka Cikitsaa 1/3/15-23 ) Step-1:}

The first step involves preparation of fine metal powder, for which, according to Carka thin metal sheets of the size $7.4 \times 7.4 \mathrm{~cm}$, easily penetrable with a thorn prick, (Caturangula Derghaani Tiloccheda tanuni Ca. Caraka Cikitsa 1/3/16 Lohaadi Rasaayana and 1 Angula $=1.95 \mathrm{~cm}$ ) (Ayurvedic Formulary of India-1978) are heated intensively to make them red hot. Then they are quenched in the following liquids in serial order: decoction of Triphalaa (fruits of Phyllanthus emblica Linn., Terminalia chebula Retz. and Terminalia belerica (Gaertn.) Roxb.), cow urine, aqueous solutions of Yavaksaahara (dried water soluble ash obtained from the Hordeum vulagare Linn.), rock salt, ingudi kshaara (dried water soluble ash of Balanites aegyptiaca (Linn.) Delile) and Palaash kshaara (dried water soluble ash of Butea frondosa Koen. Ex Roxb.). The procedure of quenching red hot metal sheets in these liquids is continued till a powder as fine and as soft as collyrium is obtained. Collyrium is a paste applied to eyes and is so fine and soft that it does not harm the corneal surface when applied to it.

\section{Step-2:}

This fine powder of metal is then mixed in honey and juice of fruits of Phyllanthus emblica and left immersed in it for about a year. The mixture is stirred intermittently once in a month. The procedure yields a semisolid mixture which is utilized as a drug. The drug can be prepared by using metal sheets of Gold, Silver, Copper or Iron in accordance with specified requirement.

In the above procedure a fine and soft metal powder is obtained after repeated quenching of red hot metal sheets in prescribed liquids in the first step. Apart from the above described formulation this metal powder can be used as an ingredient of any therapeutic formulation whenever prescribed.

\section{Method of Preparation of 'Ayaskruti' : Susruta Samhitaa (Sushruta Samhitaa 1992c).}

As in case of 'Lohaadi Rasayana' of Caraka described above, the metal is converted to powder form in this formulation also, but the procedure differs a little. In this formulation thin metal sheets are smeared with different types of salts and then heated to make them red hot. The red hot sheets are then quenched in the decoction of Triphalaa, (fruits of Phyllanthus emblica Linn., Terminalia chebula Retz. and Terminalia belerica (Gaertn.) Roxb.),and decoction of plants from Saalaasaradi group (group of plants constituting Shorea robusta Gaertn. f., Acacia catechu, Betela utilis D. Don, Gymnema sylvestre R. Br. etc for 16 times (Sushruta Samhitaa 1992d). This procedure gives 


\section{Savrikar and Afr J Tradit Complement Altern Med. (2011) 8(S):66-82}

powder of the metal sheets which is then sieved through thick muslin cloth. The sieved fine powder is utilized as a drug.

Thus both Caraka and Susruta describe the method of preparation of therapeutically useful metal powder which can be used as an individual drug entity or as an ingredient of a compound formulation. Apart from above formulations many other herbo-mineral formulations are described in the classics. Some of such formulations appearing in Caraka Samhitaa, Susruta Samhitaa and Ashtanga Hridaya are shown in Table-2.

In the period of 'Naagaarjuna', apart from introduction of 'Mercury' in therapeutics a remarkable change occurred in the method of preparation of mineral and metallic drugs. In 'Samhitaa' period the formulation of mineral and metallic preparation was restricted to preparation of fine metallic powders obtained by quenching red hot thin metal sheets in medicated liquids. In post 'Samhita' period, a new class of drug- form termed as 'Bhasma' came into existence in the science of 'Ayurvedic Pharmaceutics', with introduction of two new techniques. 'Shodhana' and 'Maarana'. The term 'Shodhana' refers to therapeutic purification whereas the term 'Maarana' refers to incineration of metals/minerals by treating them with specifically prescribed medicinal herbs, to convert hard metal/mineral into fine and soft powder termed as 'Bhasma'. The mastering of the art of 'Bhasma' preparation heralded the era of use of relatively safe and effective mineral and metallic drugs by the physicians.

The processing techniques of 'Bhasma' were painstakingly set to remove toxic effects of the source material in therapeutic doses. Physical and chemical tests were also developed to decide the safety of these drugs. The ancient texts are full of such information about testing procedures of 'Bhasma'. These tests are more or less related to the particle size, density and chemical and physical stability of 'Bhasma' under high temperature conditions. A properly processed 'Bhasma' should have following characteristics (Vaagbhata, Rasaratnasamuccaya, (1976b).

'Rekhaapoornatwa': The 'Bhasma' is said to possess this characteristic when particles of 'Bhasma' are fine enough to settle in the ridges of fingers, when rubbed between thumb and the index finger.

Vaaritaratva: The 'Bhasma', when sprinkled should float on the surface of water.

'Apunarbhawatwa' : 'Bhasma', when mixed with the mixture of Jaggery, fruits of Abrus precatorious Linn.,

Ghee, Honey and Borax and subjected to intense heating in a crucible, should never lead to reappearance of the source mineral or metal from which the 'Bhasma' is prepared. However the temperature should not be allowed to exceed the temperature used to prepare the Bhasma being tested.

Nirutthatva: The 'Bhasma' is placed in a crucible along with a piece of Silver metal weighing equal to the 'Bhasma'. The crucible is subjected to heating at a temperature equal to the temperature used for preparation of 'Bhasma' for a period of three hours. The heating should not cause any increase or decrease in the weight of piece of Silver metal. Such a change will be observed only if the 'Bhasma' is not properly prepared.

'Bhasma' failing in any of the above described tests, if consumed, will lead to toxic effects as shown in the table below (Table-3). It is noteworthy that while introducing the use of mercury and other minerals and metals in therapeutics, a caution was also issued about the harmful and toxic effects of these substances in the event of improper or inadequate processing.

'Rasausadhies' although named after mercury, can be classified in two distinct classes. 1. Mercurials and 2. Non-mercurials. Use of mercury in therapeutics revolutionized the management of disease. Use of mercury in therapeutics was started as a bio-enhancer rather than as a drug. Combination of mercury with any drug was supposed to reduce its dose and increase its efficacy manifolds.

Mercury is first processed to make it therapeutically purified (Suddha Parada) and then it is transformed into stable and non-toxic compounds which are therapeutically effective (Baddha or Murcchita Parada). The basic material used in the preparation of most of the mercury based drugs, is a compound of mercury and sulphur prepared by grinding them together. This compound of mercury is a black coloured fine powder. It is termed as 'Kajjali', due to its resemblance to collyrium, with respect to its colour and softness. Based on the method of preparation, the mercury based drugs are classified as 1. Khalvi rasa 2. Parpati rasa 3. Kupipakwa rasa and 4.Pottali rasa.

1- Khalvi Rasa: Mercury and sulphur and / or other herbal or mineral / metal ingredients are ground together in a mortar to produce a finely powdered drug. Since the mercury and other ingredients of the formulation are grinded in a mortar, known as 'Khalva' as per the terminology of Ayurved, the formulation is known and classified as 'Khalvi Rasa'.

2-Parpati Rasa: Mercury and sulphur are first ground, if prescribed, with specified metal bhasma, if not, without metal bhasma, to prepare a homogeneous black coloured fine powder termed as 'Kajjali'. The powdered mass 'Kajjali' is then subjected to controlled heating in an iron spatula to obtain a molten mass. The molten mass is then immediately poured and spread evenly on a flat soft surface, preferably on the surface of a banana leaf, which is usually placed on a soft surfaced platform prepared from fresh wet cow dung or mud. The soft material like fresh cow dung or mud is selected for this procedure to provide smooth and even platform for the leaf placed on it and to

Table 1: Classification of mineral and metal preparations used in Ayurveda 


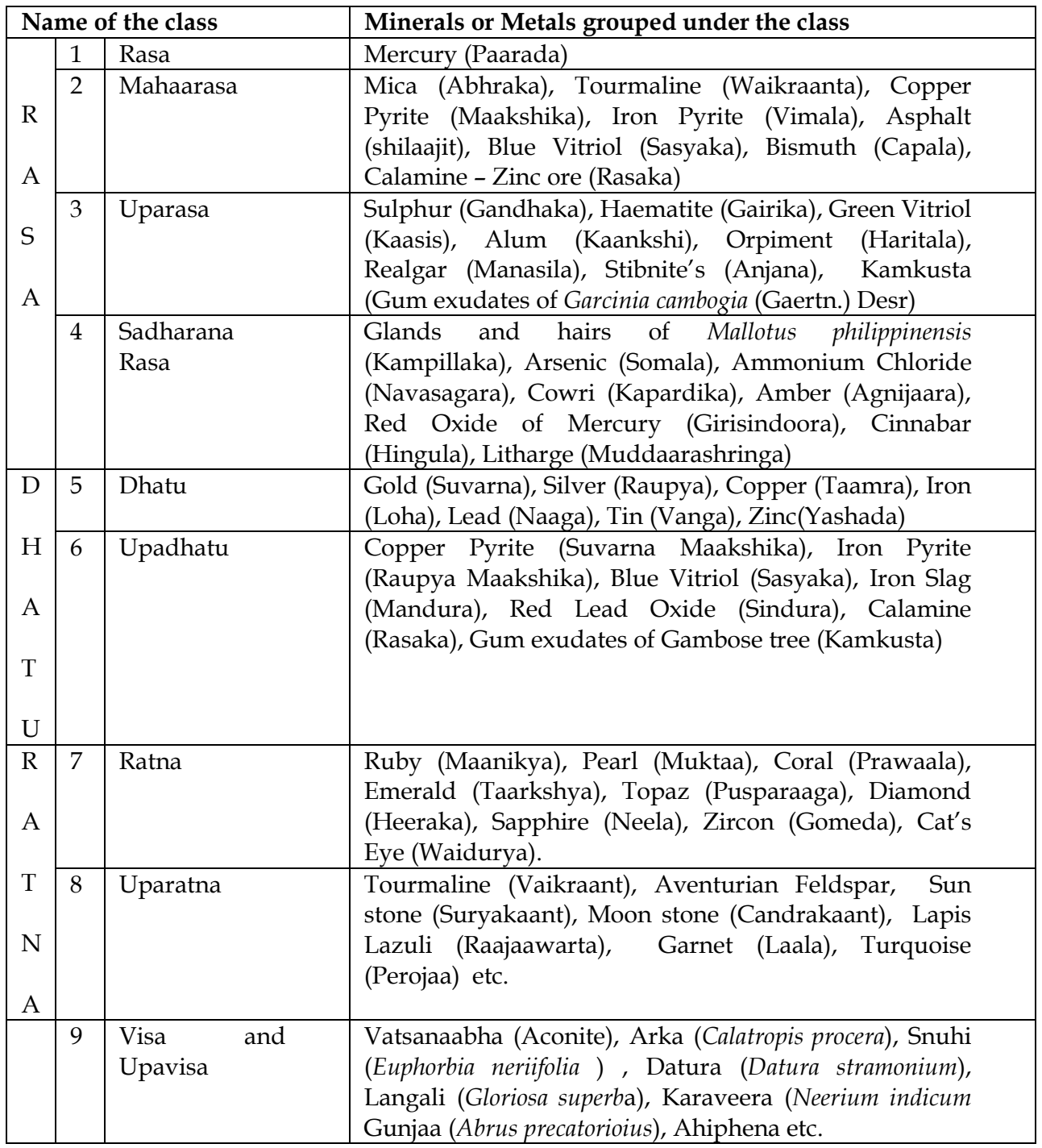

facilitate free flow and even spread of the liquefied kajjali on the surface of the leaf. The poured mass is then immediately covered with another banana leaf and is hand pressed evenly. The covered leaf is then removed to find a thin flat sheet of the material, which is termed as 'Parpati'.

Table 4 contains some important examples of this group and their therapeutic applications.

\section{Kupipakva Rasa}

Mercurial drug preparations prepared by subjecting the 'Kajjali' (a product obtained by grinding mercury with sulphur and /or prescribed mineral and metal ingredients) to controlled heating in a narrow mouth high long neck glass flask termed as 'Kupi', or sometimes in an earthenware crucible termed as 'Mushaa' or in a metallic crucible; is termed as 'Kupipakwa Rasa' .

Table 2:. Examples of Herbo-mineral formulations mentioned in 'Ayurvedic' Classics 
Savrikar and Afr J Tradit Complement Altern Med. (2011) 8(S):66-82

\begin{tabular}{|c|c|c|}
\hline $\begin{array}{l}\text { Name of the Mineral / } \\
\text { Metal }\end{array}$ & Name of Formulation & Text Reference \\
\hline Sulphur (Gandhaka) & Muktaadya Churna & Caraka Cikitsaa. 17/125-128* \\
\hline \multirow{3}{*}{$\begin{array}{l}\text { Copper Pyrite } \\
\text { (Maakshika) }\end{array}$} & Mandura Vataka & Caraka Cikitsaa 16/72-77* \\
\hline & Yogaraaja & Caraka Cikitsaa 16/80-86* \\
\hline & Tapyaadi Loha & Ashtaanga Hridaya Cikitsaa $20-22^{* *}$ \\
\hline \multirow[t]{2}{*}{ Stibnitis (Anjana) } & Muktaadya Curna & Caraka Cikitsaa 17/ 125-128 \\
\hline & Candrodaya Agada & Ashtaanga Hridaya Uttara 35/24-26** \\
\hline \multirow[t]{2}{*}{ Gold (Suvarna) } & Dwitiya Braahma Rasaayana & Caraka Cikitsaa $1 / 1 / 58-61^{*}$ \\
\hline & Yuktaratha Rasaayana & Susruta Cikitsaa. 28/15,16*** \\
\hline \multirow[t]{5}{*}{ Silver (Rajata) } & Dwitiya Braahma Rasaayana & Caraka Cikitsaa. 1/1-58* \\
\hline & Indrokta Rasaayana & Caraka Cikitsaa. 1/4/13-26* \\
\hline & Yogaraaj & Caraka Cikitsaa. 16/86* \\
\hline & Muktaadya Curna & Caraka Cikitsaa 17/125-128* \\
\hline & Taapyaadi Loha & Ashtanga Hridaya Cikitsaa 20-22** \\
\hline \multirow[t]{8}{*}{ Iron (Loha) } & Yogaraaj & Caraka Cikitsaa 16/80-82* \\
\hline & Navaayas Curna & Caraka Cikitsaa 16/70-71* \\
\hline & Muktaadya Curna & Caraka Cikitsaa 17/125-128 \\
\hline & Dwitiya Braahma Rasaayana & Caraka Cikitsaa. 1/1-58* \\
\hline & Amalakaayasa Braahma Rasaayana & Caraka Cikitsaa. 1/3-3* \\
\hline & Ayaskruti & Susruta Cikitsaa. 10/11*** \\
\hline & Navaayasa Curna & Susruta Cikitsaa. 12/11*** \\
\hline & Asanaadi Ayaskruti & Ashtanga Hridaya Cikitsaa. $12 / 32^{* *}$ \\
\hline \multirow[t]{2}{*}{ Copper (Taamra) } & Dwitiya Braahma Rasaayana & Caraka Cikitsaa. $1 / 1-58^{*}$ \\
\hline & Muktaadya Curna & Caraka Cikitsaa 17/125-128* \\
\hline \multirow[t]{3}{*}{ Iron Slag (Mandura) } & Mandura Vataka & Caraka Cikitsaa 16/ 72-77* \\
\hline & PunarnavjaMandura & Caraka Cikitsaa 16/ 93-96* \\
\hline & Mandura Vataka & Caraka Cikitsaa 16/ 102-104* \\
\hline
\end{tabular}

\section{Method of Preparation}

The drug is prepared in following stages:

\section{Stage I: Preparation of 'Kajjali'}

A mercurial drug preparation prepared by grinding Mercury with Sulphur or/and prescribed metal or mineral ingredients; to obtain a black powder as fine as collyrium is termed as 'Kajjali'.

\section{Method of Preparation of 'Kajjali':}

- Mercury along with Sulphur and other prescribed ingredient raw materials are first subjected to prescribed purification (Shodhana) procedure.

- $\quad$ Purified Mercury is then placed in a mortar (Khalva Yantra) of suitable size.

- If the prescribed ingredients contain metals, the purified metal is mixed with mercury in the mortar and the contents are ground to obtain a homogeneous mass. If metal ingredients are not prescribed, purified Sulphur and other prescribed ingredients are directly mixed with Mercury and the mixture is thoroughly and continuously grounded in a mortar till a homogeneous black coloured powder as soft and as fine as collyrium is obtained. Due to its similarity with Collyrium this powder is termed as 'Kajjali'. This 'Kajjali' is then filled in a glass flask (Kupi) which is subjected to further processing as described below in stage II. 
Table 3: Toxic effects of improperly processed Minerals/Metals

\begin{tabular}{|c|c|c|}
\hline $\begin{array}{l}\text { Name of } \\
\text { Mineral/Metal }\end{array}$ & Nature of Toxic Effect & $\begin{array}{l}\text { Textual } \\
\text { Reference }\end{array}$ \\
\hline $\begin{array}{l}\text { 1. Mercury } \\
\text { (Paarada) }\end{array}$ & $\begin{array}{l}\text { Skin disorder, Dyspepsia, Loss of immunity, } \\
\text { Vomiting, Loss of Taste, Sluggish Movements } \\
\text {, Burning sensation, death. }\end{array}$ & Anonymous (1973) \\
\hline $\begin{array}{l}\text { 2. Sulphur } \\
\text { (Gandhaka) }\end{array}$ & $\begin{array}{l}\text { Skin disorders, Hyperthermia, Giddiness, } \\
\text { Disorders of Pitta, General debility and Unease, } \\
\text { Loss of vigor and luster, Oligospermia - }\end{array}$ & Madhava (1986). \\
\hline $\begin{array}{l}\text { 3. Cinnabar } \\
\text { (Hingula) }\end{array}$ & $\begin{array}{l}\text { Blindness, General Debility, Malaise, } \\
\text { Giddiness, Intoxication, Renal disorders }\end{array}$ & Madhava (1986). \\
\hline $\begin{array}{l}\text { 4.Mica } \\
\text { (Abhraka) }\end{array}$ & $\begin{array}{l}\text { Skin disorders, Cachexia, Anemia, Oedema, } \\
\text { Chest pain, Backache }\end{array}$ & Madhava (1986). \\
\hline $\begin{array}{l}\text { 5. Orpiment } \\
\text { (Harataala) }\end{array}$ & $\begin{array}{l}\text { Loss of luster, Pain and rigidity in various body parts, } \\
\text { Skin disorders, Diseases of Vaata and Kapha }\end{array}$ & Madhava (1986). \\
\hline $\begin{array}{l}\text { 6. Realgar } \\
\text { (Manasila) }\end{array}$ & $\begin{array}{l}\text { Loss of Vigor and strength, Constipation, } \\
\text { Dysuria, Urinary calculi, Urinary obstruction }\end{array}$ & Madhava (1986). \\
\hline $\begin{array}{l}\text { 7. Borax } \\
\text { (Tankana) }\end{array}$ & Vomiting, Giddiness & Madhava (1986). \\
\hline \multirow[t]{2}{*}{$\begin{array}{l}\text { 8. Gold } \\
\text { (Suvarna) }\end{array}$} & $\begin{array}{l}\text { Loss of Vigor and Strength, Oligospermia, } \\
\text { Loss of Immunity and Death - }\end{array}$ & Madhava (1986). \\
\hline & Laborious movements, Perspiration- & Anonymous (1936). \\
\hline \multirow{2}{*}{$\begin{array}{l}\text { 9. Silver } \\
\text { (Rajata) }\end{array}$} & Sluggishness in Gastric motility, Dyspepsia & Anonymous (1936). \\
\hline & Oligopsermia, Cachexia, Malaise and body odour - & Sadanand Sharma (1989). \\
\hline $\begin{array}{l}\text { 10. Copper } \\
\text { (Taamra) }\end{array}$ & $\begin{array}{l}\text { Giddiness, Syncope, Burning sensation, } \\
\text { Perspiration, Moistening or dampening, Vomiting, } \\
\text { Loss of taste, Mental Irritation .- - }\end{array}$ & Madhava (1986). \\
\hline $\begin{array}{l}\text { 11. Tin } \\
\text { (Vanga) }\end{array}$ & $\begin{array}{l}\text { Polyuria, Tumorogenesis, Cardiac diseases, } \\
\text { Colicky pain, Hemorrhides, Cough, Dyspnoea, } \\
\text { Vomiting- }\end{array}$ & Madhava (1986). \\
\hline 12. Zinc -(Yasada) & Tumorogenesis, Polyuria, Cachexia, Skin disorders & Sadanand Sharma (1989). \\
\hline 13. Lead (Naaga) & Polyuria, Cachexia, Jaundice- & Madhava (1986). \\
\hline 14. Iron (Loha) & $\begin{array}{l}\text { Male sterility, Skin disorders, Cardiac Diseases, } \\
\text { Calculi, Colicky pain, Nausea, Death, } \\
\text { Tumorogenesis }\end{array}$ & Madhava (1986). \\
\hline
\end{tabular}

\section{Stage II : Controlled Heating of 'Kajjali':}

Heating of 'Kajjali' is carried out in a narrow mouth high long neck glass flask termed as 'Kupi' kept in a specially prepared Sand Bath termed as 'Vaalukaa Yantra'. Alternatively Electrical Muffle Furnace is also used. Preparation of 'Kupi' and 'Vaalukaa Yantra' is described below:

\section{A) Preparation of 'Kupi'}

- A clean good quality $1000 \mathrm{ml}$ round bottom glass flask with long narrow neck or $1000 \mathrm{ml}$ bottle of vertical shape and long narrow long neck is selected.

- The flask or bottle is then fully wrapped with seven layers of white clay smeared pieces of cloth (Mritkarpata) in the following manner. First layer of clay smeared wet cloth is wrapped around the flask leaving the neck unwrapped. Care should be taken that no air gap is left in between, while wrapping the cloth around the flask. The wrapped layer is then allowed to dry. As soon as the first layer dries second layer of clay smeared cloth is wrapped around the flask in the same manner as described earlier. Thus the flask is wrapped with seven layers 
of clay smeared cloth. The flask or 'Kupi' becomes ready for use when all the wrappings around it dry completely.

- The flask is now filled with 'Kajjali' specifically prepared for this procedure leaving $2 / 3^{\text {rd }}$ of the flask empty.

- The 'Kajjali' filled 'Kupi' is ready for further use.

Table 4: Some important examples of parpaties

\begin{tabular}{|c|c|c|}
\hline Name of the parpati & $\begin{array}{l}\text { Dose ( adult average) } \\
\text { and adjuvants }\end{array}$ & Therapeutic indications \\
\hline Panchamirta Parpati & $\begin{array}{l}125 \text { to } 250 \mathrm{mg}-\text { with } \\
\text { honey, ghee / Bhrashta } \\
\text { jiraka churna }\end{array}$ & $\begin{array}{l}\text { Malabsorption syndrome, haemorrhoids, } \\
\text { vomiting, diarrhoea, fever, tastelessness, } \\
\text { bleeding } \\
\text { disorder, senescence linked skin and hair } \\
\text { changes, eye disorder, } \\
\text { digestive impairment and oligospermia }\end{array}$ \\
\hline Bola Parpati & 125 to $250 \mathrm{mg}$ & $\begin{array}{l}\text { Menorrhagia or metrorrhagia bleeding disorders } \\
\text { and bleeding haemorrhoids }\end{array}$ \\
\hline Rasa Parpati & $\begin{array}{l}250 \mathrm{mg} \text { (may be } \\
\text { increased gradually up } \\
\text { to } 1125 \mathrm{mg} \text { ) } \\
\text { With milk, butter milk, } \\
\text { bhrasta jiraka and hingu } \\
\text { churna (asafoetida- } \\
\text { resin) }\end{array}$ & $\begin{array}{l}\text { Colicky pain, malabsorption syndrome, } \\
\text { diarrhoea, dysentery, inflammation, jaundice, } \\
\text { anaemia, fever, rheumatism and haemorrhoids, } \\
\text { skin disorders, dyspepsia, digestion and } \\
\text { assimilation problems, ascites, }\end{array}$ \\
\hline Lauha Parpati & $250 \mathrm{mg}$ & $\begin{array}{l}\text { Digestive impairment, malabsorption syndrome, } \\
\text { dyspepsia, anaemia, Jvara post partum fever- } \\
\text { puerperal fever, diarrhoea, jaundice, splenic } \\
\text { Diseases, polyphagia with emaciation), } \\
\text { rheumatism, diseases of skin, wrinkles in skin } \\
\text { and graying of hair. }\end{array}$ \\
\hline Svarna Parpati & 125 to $250 \mathrm{mg}$ & $\begin{array}{l}\text { Malabsorption syndrome, tuberculosis, intestinal } \\
\text { colic and oligospermia }\end{array}$ \\
\hline
\end{tabular}

Table 5: Some important examples of kupipakva rasayana

\begin{tabular}{|l|l|}
\hline Name & \multicolumn{1}{|l|}{ Major therapeutic indications (Anonymous 1978) } \\
\hline Kantavallabha rasa & $\begin{array}{l}\text { Malabsorption syndrome, spleen disorders, anemia, weakness, emaciation, } \\
\text { oligospermia, asthma, fever, management of piles etc }\end{array}$ \\
\hline Makara Dhvaja & $\begin{array}{l}\text { Weakness of the heart, Senility/Premature ageing, Fever, digestive impairment. } \\
\text { Aphrodisiac and nutrient to body and mind with adaptoimmuno-neuro-endocrino- } \\
\text { modulator properties }\end{array}$ \\
\hline Mallasindura & $\begin{array}{l}\text { Bronchial asthma; disease due to Vata and Kapha doshas } \\
\text { Kapha dosha) and Syphilis }\end{array}$ \\
\hline Rasasindura & $\begin{array}{l}\text { Diarrhoea and dysentery, worm infestation, skin and blood disorders, digestive } \\
\text { impairment, Microbial infection and Tastelessness }\end{array}$ \\
\hline Rasapuspa & Gastro-enteritis with piercing pain), ascites, dysuria etc \\
\hline Rasasindura & $\begin{array}{l}\text { Disease due to Kapha dosha, loss of strength / immunity, tissue wasting, weakness of } \\
\text { the heart, } \\
\text { colicky Pain, fistula-in-ano, tuberculosis, anaemia, obesity, ulcer etc. }\end{array}$ \\
\hline Vatagni kumara rasa & $\begin{array}{l}\text { Cough, dyspnoea/asthma, fever, Vataroga (disease due to } \\
\text { Vata dosha) }\end{array}$ \\
\hline Samirapannaga rasa & $\begin{array}{l}\text { Disease due to vitiation of all the three Doshas), stiffness in joints due to Kapha Dosha, } \\
\text { fever, dyspnoea, Asthma, cough }\end{array}$ \\
\hline Chronic cough, dyspnoea/asthma, diabetes and polyurias and diseases of urinary tract \\
\hline Svarnavanga sindura & \begin{tabular}{l} 
Oligospermia, tissue wasting, learning disability and all diseases \\
\hline
\end{tabular} \\
\hline
\end{tabular}


Table 6: Some important examples of pistis and therapeutic indications

\begin{tabular}{|l|l|l|}
\hline Name of the pisti & $\begin{array}{l}\text { Dose (adult average) } \\
\text { and adjuvants }\end{array}$ & Therapeutic indications \\
\hline $\begin{array}{l}\text { Tranakantamani pisti (Kaharuba } \\
\text { pitsi) }\end{array}$ & $250-500 \mathrm{mg}$ & $\begin{array}{l}\text { Menorrhagia or metrorrhagia bleeding disorders. } \\
\text { Diarrhoea with bleeding }\end{array}$ \\
\hline Pravala pisti (from coral) & $250 \mathrm{mg}$ & $\begin{array}{l}\text { Oligospermia, loss of strength and immunity, } \\
\text { digestive impairment, low intelligence etc. }\end{array}$ \\
\hline Mukta Pisti (from pearl) & $65-125 \mathrm{mg}$ & $\begin{array}{l}\text { Diarrhoea with bleeding, heart disease, mania } \\
\text { and psychosis, bleeding disorders }\end{array}$ \\
\hline Manikya pist i ( from ruby) & $65-125 \mathrm{mg}$ & $\begin{array}{l}\text { Loss of body strength (immunity), heart disease, } \\
\text { oligospermia, digestive impairment, weakness, } \\
\text { low intelligence }\end{array}$ \\
\hline
\end{tabular}

\section{B) Preparation of Sand Bath, the 'Vaalukaa yantra':}

A wide mouthed, round bottom, earthenware or metallic pot of $15 \mathrm{~kg}$. (approx) capacity accommodating the above described glass flask (Kupi) is selected and smeared with a thin layer of white clay from outside (in case of earthenware pot). Fine and completely dry sand is poured at the bottom of the earthenware or metallic container forming 15 to $20 \mathrm{~cm}$ thick layer at the bottom. The 'Kupi' filled with 'Kajjali' is then placed on this sand in the container. Space between the flask (Kupi) and the pot around the Kupi is then filled with the sand up to the neck of 'Kupi'. The mouth of the 'Kupi' should be temporarily covered while filling the sand around it so that sand particles will not enter in the flask and adulterate the 'kajjali'. The apparatus is now called as 'Vaaluka Yantra' and is ready to be subjected to heating.

\section{Stage III: Heating}

A specially designed 'Culhaa' (a heating device made of bricks and mud) is required for giving controlled heat to 'Vaalukaa Yantra' for preparation of 'Kupipakva Rasa'. Wood or Hard coal is usually used as fuel in this 'Culhaa'. Heating has to be continued for hours together. The 'Vaalukaa Yantra' as prepared above, holding the 'Kajjali' filled 'Kupi', is placed on the 'Culhaa'. The fire is ignited and heating is started with low flame (Mandaagni) between $100^{\circ} \mathrm{C}$ to $200^{\circ} \mathrm{C}$. As the heating is continued yellow fumes of sulphur start emerging out from the 'Kupi'. This sulphur starts accumulating in the neck of the 'Kupi' and eventually blocks it. To avoid such blocking, the neck of the 'Kupi' should be cleaned intermittently with a slender hot iron rod.

Fumes of sulphur will keep emerging out of the 'Kupi' for about 6 to 8 hours, till all free sulphur gets burnt. The period will vary according to the composition and quantity of 'Kajjali' inside the 'Kupi'. The temperature of the 'Kupi' should be maintained between $200{ }^{\circ} \mathrm{C}$ to $225{ }^{\circ} \mathrm{C}$ (Madhyamaagni) during this period. At the end of about 6 to 8 hours fumes of sulphur will stop coming out from the 'Kupi' and the inside bottom of the 'Kupi' appears angry red just like a bright red sun. This is an indication that the time of closing the mouth of the 'Kupi' has come. At this juncture a cork tightly fitting in the mouth of the 'Kupi' is put in the mouth of the 'Kupi' and it is tightly closed. It is then properly sealed with specially prepared sealing material. After the sealing the fire in the 'Culhaa' is increased so that the temperature of 'Kupi' will rise to $225{ }^{\circ} \mathrm{C}$ to $360{ }^{\circ} \mathrm{C}$ (Tivraagni). The heating of 'Kupi' at this temperature range is continued for about three hours. (The temperature ranges are given as observed in preparation of Rasasindura* Vasudev Dvivedi, 'Paarad Vigyaaniya').

At the end of three hours heating is stopped and the apparatus is left to cool on its own. The 'Kupi' is then taken out of 'Vaaluka Yantra' when it becomes completely cold. This may take 10 to 12 hours.

\section{Stage IV: Process of opening of Kupi}

Process of opening of 'kupi' is actually breaking of 'kupi' - the glass bottle, in middle in two halves. A thick cotton thread soaked in kerosene is tied around the middle of the 'kupi'. The soaked thread is ignited, and allowed to burn completely. This is followed by sprinkling of water on the 'kupi' where it is hot due to burning of thread. This causes breaking of 'kupi', exactly in two halves. According to the type of drug formulation the end product of the 
process i.e. 'Kupipakva Rasaayana' will get collected in the upper half, lower half or both the halves of the 'kupi'. The drug collected in the upper half i.e. in the neck of bottle is termed as 'Kanthastha Rasaayana', the drug collected in the lower half i.e. in the bottom is known as 'Talastha Rasayana' and the drug collected in both halves will be known as 'Ubhayastha Rasaayana'.

This drug is skilfully collected by scrapping the sides of 'Kupi' from respective parts, taking care that broken glass particles do not get mixed with the drug. Collected drug is then subjected to dry grinding in a mortar to prepare fine powder which is stored in a suitable airtight container.

4- Pottali Rasa: The 'Kajjali', prepared with prescribed ingredients is wrapped tightly in a silk cloth to prepare a bundle termed as 'Pottali'. Sulphur powder of required quantity is taken in a stainless steel or earthenware wide mouthed pan. The pan is kept on fire and the sulphur is allowed to melt. The molten sulphur serves the purpose of sulphur bath for the 'pottali'. The above described bundle of 'kajjali' i.e. pottali is immersed in the sulphur bath, which is subjected to intensive heating. (Adequate temperature to keep the Sulphur in a molten sate for a reasonable period to achieve hardening of the mass being fried, is maintained.) The powder mass of 'Kajjali' bundled in silk cloth gets hardened by this intensive heating and gets converted into a hardened ball termed as 'Pottali' Rasa. The silk cloth wrapped around the 'kajjali' is burnt during the process and sticks to the hardened ball. This burnt cloth is removed by scratching the hardened ball, which then becomes ready for use.

The hard ball is rubbed on a stone slab moistened with water and the paste generated due to rubbing is collected and given to the patient for licking. The rubbing is performed in circular motion. The number of rounds of rubbing will be decided in accordance with the requirement of the prescribed dose of the drug. The 'Pottali Rasa' is said to be most instantly acting drug formulation among all and is usually prescribed in medical emergencies.

Minerals and metals other than mercury are also subjected to 'Shodhana' and 'Maarana' processes. In the process of 'Shodhana', the material is subjected to grinding in a prescribed liquid media or heated and quenched or bathed in a suitable hot liquid media like cow milk, butter milk, cow urine, sesame oil or decoction or extracted juice of specified medicinal plant. The material is sometimes kept soaked overnight or boiled in liquid media for a prescribed period. Whereas sometimes the material is cooked in cow milk, sour vinegar or lime water in the process of 'Shodhana'. In case of Gandhaka (Sulfur), in one of the Shodhan procedures, the Sulfur powder is first melted in cow ghee and then the mixture of Sulfur and Ghee is filtered through a muslin cloth in a container filled with cow milk. The Sulfur collected at the bottom of the container is obtained, which is washed with hot water and subjected to drying. In the process of 'Maarana' therapeutically purified material is subjected to grinding with prescribed medicinal plant decoctions, juices etc., followed by incineration of ground material in a closed earthenware container to obtain fine and soft calcined product called 'Bhasma'. Some of the minerals such as 'Sulphur', Haemetite, Alum, Borax etc. do not require incineration as they are very soft and palatable in their natural form. They are simply subjected to therapeutic purification i.e. 'Shodhana' for removing impurity and toxicity.

Sometimes the 'Bhasma', although prepared carefully cannot get rid of properties or ingredients which prove harmful and toxic to the body. In such circumstances the 'Bhasma' is subjected to further processing. These procedures are termed as 'Amritikarana' and 'Lohitikarana'. This is generally practiced in case of 'Abhraka Bhasma' (Bhasma prepared from Mica). In 'Amritikarana' the Abhraka Bhasma is cooked with ghee and decoction of 'Triphalaa'. In 'Lohitikarana' the Abhraka Bhasma is once again subjected to incineration with the prescribed medicinal plants.

\section{Method of preparation of 'Bhasma'}

Bhasma is prepared in two major steps 1. 'Shodhana' and 2. 'Maarana'. However some minerals and metals like Biotite mica and copper may require additional steps like 3. 'Amrutikarna' and 4. Lohitikarna.

\section{Step 1. 'Shodhana':}

Literally 'Shodhana' is a process of purification. But this purification in real sense is not limited or restricted to physical or chemical purification. In fact although achieved to some extent, physical or chemical purity of the material is not an ultimate objective of the 'Shodhana' process. On the contrary the processed material may contain some foreign particulates at the end of the 'Shodhana' process. But the processed material will definitely be ready to be used as a drug ingredient or as a raw material for further processing i.e. 'Maarana'. Thus 'Shodhana' process is essentially targeted to pharmaceutical utility rather than physical and chemical purity of the material under process. Objects of the 'Shodhana' thus can be summarized as follows: 


\section{Savrikar and Afr J Tradit Complement Altern Med. (2011) 8(S):66-82}

(a) Removal of visible foreign material like dust, gravel etc. (b) Elimination, attenuation or pacification of harmful biological activity of the drug, (c) Modification of undesirable physical and chemical properties of the drug; (d) Enhancement of intended therapeutic action (e) Preparation of the material for further processing.

At the end of the 'Shodhana' process some of the minerals like Sulphur, Haemetite, Alum etc. become ready for use as a drug or drug ingredient. However other minerals and metals have to undergo further processing to become ready as a drug or drug ingredient and hence are subjected to 'Maarana'. The end product of the 'Shodhana' process is termed as 'Suddha dravya'.

\section{Step 2: 'Maarana':}

Minerals like Mica, Pyrite ores and metals are very hard in consistency. Although this consistency is reduced to a reasonable extent in the process of 'Shodhana', still it remains a major obstacle in making it palatable. Under the circumstances such materials are subjected to further processing termed as 'Maarana'. Apart from making the substance soft and palatable the procedures also augment the intended therapeutic efficacy of the product in accordance with the ingredient material used in the processes.

The object of 'Maarana' is to obtain powder of the material, termed as 'Bhasma', as fine and as soft as 'collyrium'. 'Collyrium' is a medicament applied in the eye. It is so fine and so soft that on application it does not cause any physical injury to the corneal surface. Simple intensive heating of the material at high temperatures does not achieve this objective. The material needs to be processed with prescribed substances in a prescribed manner. This procedure is termed as 'Maarana'. 'Maarana' is principally a process of incineration or calcination. It is carried out in following stages:

\section{'Bhaavana' (Wet grinding) and 'Putapaaka' (Incineration)}

1. 'Bhaavana' (Wet grinding): Grinding of the material, completely soaked in prescribed liquid media, till the liquid is completely evaporated and the material is dried, is termed as 'Bhaavana'. Sometimes the material may be soaked and left for drying on its own without grinding.

'Shuddha dravya', the end product of 'Shodhana' process is a basic raw material in the process of 'Maarana'. This basic raw material is subjected to wet grinding in the juices or decoctions of prescribed plant material. The wet grinding is stopped when the contents in the grinder are converted into dough. The dough is then cut into pellets of required size. The pellets are preferably air dried and then subjected to further processing i.e. 'Putapaaka'.

2. 'Putapaaka' (Incineration): As the word in bracket suggests 'Putapaaka' is essentially a process of incineration. But this has to be carried out in a prescribed manner. The process requires specific equipment, consisting of a heating device called 'Puta', in the form of a trough of measured size, dug into the ground and filled with cow dung cakes used as a fuel, and a closed earthenware container called 'Sharaava samputa', containing dried pellets of processing material.

The dried pellets obtained at the end of first step as described above are placed in an earthenware shallow plate. The earthenware plate is termed as 'Sharaava'. The filled plate is then closed with another earthenware plate of same size, putting it upside down. The joint of the two plates is sealed with proper sealing material. This closed joined earthenware container is termed as 'Sharaava samputa'. The 'Sharaava samputa' so prepared is to be placed in the 'Puta', the heating device in the form of trough filled with dried cow dung cakes as described above. The 'Sharaava samputa' has to be placed in the trough on the surface of cow dung cakes, filled up to one third of the trough. Rest of the two third of trough is to be filled with more cow dung cakes. The cow dung cakes are then ignited and left to burn to ashes. It is then left to cool of its own. The earthenware sealed pot is then removed from the trough. It is then opened by breaking the seal and the contents are collected and ground in a mortar to prepare fine powder.

The process starting from 'Bhaavana' (wet grinding) to the completion of 'Putapaaka' (incineration) constitutes one 'Puta'. This 'Puta' process needs to be repeated till a fine powder i.e. 'Bhasma' of required quality is obtained. Usually number of 'Puta' required to prepare 'Bhasma' of required quality are prescribed by the texts, however if the 'Bhasma' fails to pass through the prescribed tests at the end of prescribed number of 'Puta', the "Puta' process needs to be continued further till 'Bhasma' passing through all the tests is obtained.

The 'Puta' is defined as a device to provide measured amount of heat to produce adequately digested product (Vaagbhata 1976c Rasaratnasamuccaya'.10/47) The 'Putas' (method of heating) are described under different names to indicate the size of the pit and the number of cow dung cakes to be used as fuel. Full details on them can be obtained from Ayurvedic Formulary of India part-1 Appendices Glossary of technical terms (Anonymous -1978).

Twenty two types of 'Bhasmas' are mentioned in Ayurvedic Formulary of India (Anonymous 1978). Information about their therapeutic application and dosage can be found in it. 


\section{Savrikar and Afr J Tradit Complement Altern Med. (2011) 8(S):66-82}

Importance of Mercury in Ayurvedic Pharmaceutics

Importance of Mercury in the Ayurvedic pharmaceutics is evident from the fact that the name of pharmaceutical science related to minerals and metals is derived from the name of the Mercury itself. This importance is attributed to Mercury on account of its possession of unique physical, chemical and pharmaceutical characteristics. Ayurvedic scientists working in the field of 'Rasashaastra' have skilfully exploited these characteristics to make the drug therapeutically more and more useful, active and potent. Mercury is liquid in nature at normal temperature. It combines very easily with other elements and forms stable compounds. Therapeutically these compounds are said to be much more active than the original element. A unique characteristic of Mercury termed as 'Yogavaahitva' plays a significant role in this respect. Substances possessing 'Yogvavaahi' characteristics, when combined with others besides maintaining their own activity, increase the therapeutic activity of the other substance many folds.

Yaddravyam Dravyaantarenaanugunenaapi Yuktam Sattadgunaananuvartate swam ca Kaaryam Tad avirudham Kincit karoti. Tadyogavaahi Dravyam Bhrityavat. Yathaa Bhrityah Swaamikaaryam atyajan Swakaaryamapi Shareerayaatraadikam Swaam aviruddham Karoti--. Arunadatta (1982).

As a result the dose of the drug and time required for the onset of action is considerably reduced. It can be said that the bioavailability of the drug is increased due to the action of Mercury. Thus Mercury can be treated as a bio-enhancer agent in Ayurvedic pharmaceutical science. 'Rasavaidyaas' use characteristics of Mercury, as a standard of pharmaceutical actions of mineral and metallic drug preparation. Particularly in case of metal 'Bhasma' it is said that the metals when converted into 'Bhasma' acquire the characteristics of Mercury and become capable of strengthening the body and curing the disease. In this respect a term 'Rasibhavana' meaning becoming 'Rasa' is used. 'Rasibhavana' also refers to the ability of Bhasma to assimilate in the Rasa i.e. nutrient fluid circulating inside the body after administration.

The term indicates that metals after getting converted into 'Bhasma' behave just like Mercury. In other words pharmaceutically they become equally effective as Mercury.

Mritaani Lohaani Rasibhavanti Nighanti Yuktaani Mahaamayaansca.

Abhyasyogad Dridhadehasiddhi, Kurvanti Rug jaravinasanam.

(Vaagbhata 'Rasaratnasamuccaya' 5/142,1976d)

Metal bhasmas are prepared by treating the metals with different types of substances. However 'Bhasmas' prepared by treating the metals with Mercury are supposed to be superior in all respects. Following quotation throws adequate light on this aspect.

Lohaanaam Maaranam Sreshtham Sarveshaam Rasabhsmanaam.

Mulibhirmadyamam praahur Kanistham Gandhakaadibhihi.

Arilohen lohasya Maaranam durgunapradam.

(Vaagbhata 'Rasaratnasamuccaya', 5/13, 1976e),

Metal 'bhasmas' prepared by treating the metal with mercury are superior in quality with respect to therapeutic activity. 'Bhasmas' produced by treating the metal with plant material are of medium quality, those produced by treating the metal with sulphur are inferior in quality and metal bhasmas prepared by treating metals with enemy metal (Ari-loha) are supposed to be harmful to the body.

Thus mercury is found used abundantly in preparation of mineral and metal drugs in Ayurvedic pharmaceutics. Being the most toxic and poisonous substance, modern medical science negates internal use of mercury and its compound in every respect. In fact extra cautions are issued to avoid physical contact with mercury and its compounds. On this background use of mercury in Ayurvedic pharmaceutics in such abundant amount appears controversial. Attempt is made below to allay the fear regarding use of mercury and the controversy about its safe use in humans.

It is noteworthy that mercury is widely used in Ayurvedic drugs in the form of Mercuric sulphide (HgS), an inorganic compound of mercury. Rarely other inorganic compounds of mercury such as mercuric chloride are used. Such use is restricted and always advocated with a specific caution regarding its toxicity. It is a well known fact that negligible amount of sulphide compounds of mercury are absorbed through G.I. tract and hence are non-toxic in nature. Organic compounds of mercury like methyl mercury and mercury vapours are highly poisonous. Compounds of mercury tend to be much more toxic than the element itself, and organic compounds of mercury are often extremely toxic and have been implicated in causing brain and liver damage. The most dangerous mercury compound dimethylmercury, is so toxic that even a few microliters spilled on the skin, or even a latex glove, can cause death.* The Karen Wetterhahn story. Acute cases usually result from inhalation of high concentrations of mercury vapor, which is produced when the metal is heated in an enclosed space (Sexton DJ, Powell KE, Liddle J, et al. 1979).

It is to be noted that these forms of mercury are never used in Ayurvedic medicine. It is also to be noted that toxic effects of mercury and methods of eliminating the toxicity of mercury have been intensely argued and described 


\section{Savrikar and Afr J Tradit Complement Altern Med. (2011) 8(S):66-82}

in Ayurvedic texts. A caution has been also issued by the 'Rasaacaaryaas' regarding toxic effects of mercury along with treatment of mercury toxicity.

It was known to 'Rasavaidyas' that mercury is a most unstable and chemically reactive substance. It readily attracts variety of impurities. As a result mercury passively absorbs atmospheric impurities. Mercury has a tendency to easily amalgamate with other metals and form amalgams. Hence it is difficult to obtain mercury in chemically purified form. Vigorous processing is required to get rid of impurities from mercury. According to classical texts of Rasashaastra various types of impurities (Dosha) are found in mercury. These impurities or Paarada dosha are broadly classified as Naisargika dosha, Yougika dosha and Aupaadhika or kancuka dosha (Vaagbhata, Rasaratna Samuccaya 11. 1976a ) Processing techniques as simple as grinding with lime powder and garlic paste with common salt and complex processes of Ashtasamskaara (eight samskaaraas) are prescribed to remove these impurities (Paarada Vigyaaniya Vasudev Dvivedi, (1978).

In this respect general as well as specific methods of purification are prescribed by 'Rasaacaaryaas'. General methods are prescribed with an object of getting rid of common impurities and obtain mercury, which is harmless to the body and suitable for further processing. Specific purification processes for purification of mercury are prescribed with an object to remove specific impurities like lead, tin etc. from mercury. In these procedures mercury is treated with specific substances in relation to the targeted impurity.

According to 'Rasaacaaryaas', Mercury is utilized in Medicine and Alchemy. Method of putting Mercury to medicinal use is known as 'Deha vaada'. Use of mercury in Alchemy is termed as 'Dhaatu vaada'. In medicine mercury is used a) as a general medicine in diseased states and b) as a 'Rasaayana' drug. Purification procedure of mercury depends on its intended use. Simple procedures such as washing and grinding with plant juices like betel leaf juice, garlic paste and lime water are prescribed when mercury is to be used as a drug in diseased state. However intensive and complex processing is required when mercury is to be used as a 'Rasaayana' or it is to be used for the purpose of 'Alchemy'. Eight and eighteen independent procedures have to be carried out respectively for 'Rasaayana' and 'Alchemy'. These procedures are grouped as 'Ashtasanskaara' comprising eight and 'Ashtaadasha sanskaara' comprising eighteen independent procedures.

Other dosage forms

Apart from 'Bhasma', two more dosage forms of minerals are also used. They are 'Pisti' and Satwa. 'Pisti' is prepared from minerals of gem quality. The purified minerals are subjected to wet grinding with prescribed liquids till a fine, dry powder is obtained, whereas 'Satwa' is prepared by subjecting the source material to intensive heating with borax at very high temperature.

\section{Shelf life of 'Rasaushadhies'}

Lot of controversy exists regarding the shelf life of 'Rasaushadhies' and metallic, mineral and herbomineral drug preparations. It has been described in the classics that the 'Rasaushadhies' retain their shelf life for infinite period. (Shaarangdhara, 'Shaarangdhara Samhitaa', 1983). Rule 376 S / GI 09-2 161B was inserted in Drugs and Cosmetics (Sixth Amendment) Rules 2009, which came into force w. e. f. $1^{\text {st }}$ April 2010 to approve this claim. (http://www.ipapharma.org/pt/December2009/PharmaScene.pdf).

This statement needs to be understood cautiously. It has been observed that 'Rasaushadhies' in terms of chemistry - the compounds produced as drugs tend to dissociate after some period, although the period extends in years. In case of 'Kajjali', it is observed that 'Kajjali' is dissociated within a period of few months. In such circumstances these 'Rasaushadhies' can not retain their shelf life for infinite period. In fact the dissociated product needs to be reprocessed. After reprocessing the product can be put to reuse. Therefore 'Rasaushadhies' need to be tested at fixed intervals, depending upon the nature of the product compound for examining the stability of their compound form. The only difference between plant or animal product based drugs and mineral or metal drugs is that mineral and metal drugs can be reprocessed and put to reuse whereas plant and animal product based drugs need to be discarded when they loose their shelf life. In this reference, the statement of the classics that 'Rasaushadhies', retain their shelf life for infinite period sounds to be true.

\section{Mineral and metal based preparations mentioned in Ayurvedic Formulary of India}

Ayurvedic Formulary of India (Anonymous 1978) is the official document which provides information on 444 classical Ayurvedic formulations most commonly used in the country. These preparations include diverse products like: churna, gutika, vati, asava, arista, modaka, khanda, guggulu, rasaayana, taila, vatika, anjana etc. They also include 22 independent mineral and metal based 'Bhasmas' and number of herbo-mineral formulations. 


\section{Savrikar and Afr J Tradit Complement Altern Med. (2011) 8(S):66-82}

\section{Rasashaastra- in recent times}

The matter related to the usage of metal and mineral based preparations for the therapeutic purpose is among one of the most controversial issues of the present day. There are two schools of thoughts. The first one represented by practitioners of 'Rasaushadhis' and their patrons. The second represented by western thought oriented persons. Those favouring their use point out towards the fact that 'Rasaushadhis' are being used as therapeutic agents since more than thousands of years by now. Ayurvedic classics clearly mention that they are potent drugs and should be used judiciously. Those opposing them point towards the enormous data generated during the last century about the serious toxicity producing potential of most of the metal based products. However, the issue is not as simple as it looks to be. There are a number of important issues that are required to be considered. It is generally observed that metals are toxic but metallic compounds such as sulphides are not toxic in therapeutic doses. The main issue to be considered is whether the metal and mineral based preparations mentioned in Ayurvedic classics and other traditional systems of medicine are safe and efficacious.

Several studies carried out over the years (Ravishankar et al 2007 and 2009) and many recent studies (Lavekar et al 2009a, b, c) ( Savrikar et al 2009) show that toxicity is not normally observed at the therapeutic dose level if used in an appropriate manner. Since they are potent products toxicity potential is inherent especially, if used in an in-appropriate manner and in in-appropriate conditions. Further there are other factors which are not drug related rather related to how the drug is prepared. There are only few top class experts who have practical knowledge of preparing these drugs which require highly skilled, often laborious techniques. There is dearth of universally accepted standard operative procedures (SOP) for the manufacturing of these drugs. There is lack of standardization in all aspects. Many a time modernization of the technique is undertaken without assessing the impact of such changes on the safety and efficacy of the final product. Thus the urgent need is for standardization of all aspects of their preparation. One of the most important but often neglected aspects is the source of starting material used. It is quite possible that the raw material may be contaminated by unwanted metals since most of the sources especially ores used in the metal extraction usually have more than one constituent. Being potent substances it is essential that only properly prepared formulations are used therapeutically.

\section{Biological activity in some of the classical metal and mineral based preparations}

Two gold preparations- Ayurvedic Swarna Bhasma and Unani Kushta Tila Kalan have been shown to attenuate stress induced elevation in the brain biogenic amines level and restore most of the stress altered parameters to normal level indicating presence of anti-stress and anti-depressant activity (Zahoor Ahmad Shah et al (2005). Another study on calcined preparations of gold and silver used in Ayurveda (Swarna bhasma, Raupya bhasma) and Unani Tibb (Kushta Tila Kalan, Kusha Nugra), thin silver foils used in India on sweets and betel and on tonic pills (chandi wark) and oral gold preparation (Auranofin) used in modern medicine in a battery of more than 30 screening tests showed that both gold and silver preparations possess analgesic, nootropic and anxiolytic effects. Besides this anti-cataleptic effect in gold preparations and anti-aggressive effect in silver based preparations have also been reported (Bajaj, S and Vohora, S.B. 2000).

Swarna bhasma (gold based) is also reported to possess analgesic, immunomodulation, anti-oxidant effects especially in ischemic conditions and anti-arthritic effects in experimental animals (Sheikh Raisuddin-2004). Tamra bhasma (copper based) has been reported to possess hepatoprotective, anti-oxidant and anti-ulcer (gastroprotective) effects. Abhrak bhasma (mica based) is reported to possess hepatoprotective, anabolic, immunomodulation effects (Sheikh Raisuddin-2004). Herbomineral formulation containing sankha bhasma (conch based) is reported to have produced good anti-duodenal ulcer effect in rats. Jasad bhasma (zinc based) has been evaluated for possible myopia arresting effect. Mukta shukti bhasma has been reported to possess good antiinflammatory activity in different models. Hepatoprotective activity has been reported with mandura bhasma (iron based) (Sheikh Raisuddin-2004). This bhasma has been shown to possess a variety of important activities especially cytoprotecive effect- against different types of experimental ulcers- (Mitra, S.K. and Rangesh, P.R.-2004). Shataavari mandur is reported to have produced good effect in cases of non ulcer dyspepsia (Sairam, K. and Batchu, S.V. 2004).

Shilaajit (a type of rock exudate) produces anti-inflammatory and anti-depressant effects (Saxena-1995). Siddh makardhwaj containing formulation and swarana bhasma are reported to possess nootrophic effect (Vohora, D.S. and Mishra, L.C. 2004). Some of the herbomineral preparations have been reported to possess useful effect in clinical depression (Singh, R.H. and Mishra, L.C. 2004). Loha bhasma's efficacy in the treatment of anaemia is well known and it is experimentally verified (Pandit $S$ et al-1999). Some of the herbomineral preparations like Ayush-82; MA-471, Abraga chendooram have been reported to be beneficial in the treatment of Diabetes mellitus (Mishra L. C. and Adra T-2004). Karpura shilaajit bhasma, an Ayurvedic herbo-mineral formulation was found to possess diuretic effect (Saleem et al 2006); Jasad bhasma (Zinc based) is reported to have produced potentiation of hypoglycemic effect of tolbutamide (Kulkarni and Gaitonde- 1962). Genotoxicity studies on four preparations - Rasa manikyaras, Lauha 
bhasma, Tamra bhasma and Kajjali bhasma employing micronucleus and comet assays showed them to be devoid of genotoxicty ( Sathya et al 2009)

\section{Future requirements}

A central repository of all the well known 'bhasmas' has to be created preferably involving government agencies so that anybody who wants to obtain reference material for comparison can do so. Standardization of all aspects of 'Bhasma' preparation including SOPS for their manufacturing should precede the formation of this central repository. This should be followed by initiation of detailed toxicity studies to define the toxicity profile of at least all the mineral and metal based single, compound metal and compound herbo-mineral preparations based on commonly acceptable protocol. While evolving standardization procedures at different levels there may be necessity for testing the activity of the intermediary and final products. For this purpose a simple assay system like zebra fish and zebra fish embryo based in vivo and in vitro tests may be developed. Zebra fish genes demonstrate on average greater than 75\% similarity to human genes (http://www.reference.com/browse/zebrafish.). Recently high through put in vitro assay systems have been developed for testing ADME (absorption, distribution, metabolism and excretion) aspects of candidate drugs, possibility of employing this technique can be considered. There is an urgent need to evolve suitable analytical methods to study and establish- the nanoparticulate character, chemical composition and other related aspects of rasaushadhies.

Thus there is sufficient evidence to show that mineral and metal based preparations used in Ayurveda and other traditional systems of medicine does have important biological activities. It is not prudent to discard such an important component of Ayurvedic therapeutic armamentarium without taking in to consideration all the aspects related to the issue. Further it is to be clearly understood and appreciated that in comparison to plant based preparation these preparations have higher toxic potential especially if used in an inappropriate manner hence should be used with caution.

\section{References}

1. Anonymous, (1936). 'Nighantu Ratnaakara', Part-1 Edited by Karisnashastri Navre, Nirnaya sagar Press, Mumbai (India) .

2. Anonymous (1973). 'Yogaratnakar- , Poorwaardha'. Edited by Brahmshankar Shastri, Second edition , Chowkhambha Sanskrit Series Office, Varanasi (India). Page 151.

3. Anonymous (1978). The Ayurvedic Formulary of India, Ministry of Health and Family Welfare, Govt. of India, New Delhi.

4. Anonymous (1978). The Ayurvedic Pharmacopoeia of India, Ministry of Health and Family Welfare, Govt. of India, New Delhi.

5. Anonymous,(2004). "(Raseshvara darshan, quoted in Maadhvaacaarya, 'Sarvadarshana Samgriha' Dr. Umashankar Sharma 'Rishi'- Ed). Chowkhambha Vidya Bhavana, Varanasi, 221001, (India) , page- 329

6. Anonymous (2006). The Karen Wetterhahn story - http://www.chm.bris.ac.uk/motm/dimethylmercury/dmmh.htm. Accessed on 9-3-2010.

7. Anonymous, OSHA update following Karen Wetterhahn's death OSHA Safety Hazard Information Bulletin on Dimethylmercury http://www.osha.gov/dts/hib/hib_data/hib19980309.html. Accessed on 9-3-2010.

8. Arunadatta, 'Sarvaangsundar' Commentary of Ashtaanga Hridaya'. Mentioned in Vaagbhata (1982). (Hari Shastri Paradakar- Ed), 7th edition, Choukhambha Orientalia . Varanasi (India). Page-76.

9. Bajaj, S and Vohora, S.B. (2000). Anti-cataleptic, anti-anxiety and anti-depressant activity of gold preparations used in Indian systems of medicine. Indian J Pharmacology: 32: 339-346.

10. Caraka Samhita with Aayurved Dipika commentary by Cakrapaani edited by Vaidya Jadavaji Trikamji Acharya (1984a). Sutra Sthaana 26/12. Choukhmba Sanskrita Sansthan, Varanasi (India).

11. Caraka Samhita with Aayurved Dipika commentary by Cakrapaani edited by Vaidya Jadavaji Trikamji Acharya (1984b). Sutra Sthaana 1/68. Choukhmba Sanskrita Sansthan, Varanasi (India).

12. Caraka Samhita with Aayurved Dipika commentary by Cakrapaani edited by Vaidya Jadavaji Trikamji Acharya (1984c). Cikitsaa Sthana 1/3/15-23. Choukhmba Sanskrita Sansthan, Varanasi (India).

13. Caraka Samhita with Aayurved Dipika commentary by Cakrapaani edited by Vaidya Jadavaji Trikamji Acharya (1984d). Cikitsaa Sthana, 1/1/58-61, /3-3, 1/4/13-26, 16/70-71, 16/72-77, 16/80-86, 16/ 93-96, 16/ 102-104, 17/125-128. Choukhmba Sanskrita Sansthan, Varanasi (India).

14. Gulraj Sharma Commentary on Maadhava Upaadhyaaya, ‘Ayurved Prakash’ (1987). Chowkhambha Bharti Academy Varanasi 221001 (India). Page- 2 
15. Kulkarni, R.D. and Gaitonde, B.B. (1962). Potentiation of tolbutamide action by Jasad Bhasma and Karela (Momordica charantia ). Indian J Med.Res. 50:715-719

16. Lavekar, G.S., Ravishankar,B, Venugopal Rao, S, Gaidhani, S, Ashok, B.K. and Shukla, V.J. (2009a). Safety /toxicity studies of ayurvedic formulation- Navratna Rasa. Toxicology International. 16(1): 37-42.

17. Lavekar, G.S., Ravishankar,B, Venugopal Rao, S, Shukla, V.J. Ashok, B.K. and Gaidhani, S, (2009b). Safety /toxicity studies of Ayurvedic Formulation- Mahadudarshan Ghan Vati. Indian Drugs. 46(11): 20-29.

18. Lavekar, G.S., Ravishankar,B, Venugopal Rao, S, Shukla, V.J. Ashok, B.K and Gaidhani, S, (2009c). Safety/toxicity study report of some Ayurvedic drugs- 2009. Central Council for Research in Ayurveda and Siddha, New Delhi.

19. Madhava,' (1986). Ayurveda Prakaash', Third Editon- 3/115,116 . 2/18, 2/74, 2/103,

20. 2/177, 2/219, 2/244, 3/39, 3/115,116, 3/154, 3/188, 3/224. Choukhambha Bhrati, Academy, Varanasi(India).

21. Mishra, L.C and Adra, T (2004). Diabetes Mellitus (Madhumeha). In Scientific Basis for Ayurvedic Therapies. Mishra, L.C. Ed. CRC-Press- London.pp-101-132.

22. Mitra, S.K. and Rangesh, P.R. (2004). Hyperacidity (Amlapitta). In Scientific Basis for Ayurvedic Therapies. Mishra, L.C. Ed. CRC-Press- London. pp-340-353.

23. 22. Pandit, S, Biswas, T.K., Debnath, P.K., Saha, A.V., Chowdhury, U., Shaw, B.P., Sen, S and Mukherjee, B . (1991). Chemical and pharmacological evaluation of different ayurvedic preparations of iron J. Ethnopharmacol. 65(2); 149-156.

24. Ravishankar, B., Shukla, V.J., Prajapati., P.K. and Co-workers (2007). A review of the safety aspects of bhasmas and bhasma based preparations used in Ayurvedic Therapeutics. Souvenir- WHO- Sponsored Seminar Cum-Worshop on Safety profile of Ayurvedic Dosage Forms. 30th and 31st October, 2007. IMS- Banaras Hindu University, Varanasi-2007.

25. Ravishankar, B and V.J.Shukla (2009). A review of the safety and efficacy aspects of metal and mineral based preparations . Special feature article: Ayurline - Ayurvedic Drugs Index. Research Special. Bangalore.

26. Sadanand Sharma, (1989). 'Rasatarangini' , 16/5, 19/97, Motilal Banarasidas, Varanasi (India)

27. Sairam, K. and Batchu, S.V. (2004). Gastroduodenal Ulcers. In Scientific Basis for Ayurvedic Therapies. Mishra, L.C. Ed. CRC-Press- London. pp-393-410.

28. Saleem, A.M., Gopal, V., Rafiullah, M.R.M. and Bharathidasan, P (2006). Chemical and pharmacological evaluation of karpura shilajit bhasma, an ayurvedic diuretic formulation. African Journal of Traditional, Complementary and Alternative Medicines. 3(2):27-36.

29. 28 . Sathya, T.N. Murthy, B and Vardhini, N (2009). Genotoxicity evaluation of certain Bhasmas using Micronucleus and Comet assays. The Internet Journal of Alternative Medicine 2009 : 7(1): no page numbers given.

30. Savrikar, S. S., Lagad C. E. (2009). 'Preparation of Bhasma' in “Anonymous” Research Study profile of Rasamanikya” Central Council for Research in Ayurveda and Siddha, New Delhi.

31. Saxena, S (1995). Silajatu Viniscaya. Ph.D. Thesis submitted to Gujarat Ayurved University, Jamnagar.

32. Sexton DJ, Powell KE, Liddle J, et al (1979). A non-occupational outbreak of inorganic mercury vapor poisoning. Arch Environ Health. 33:186-191.

33. Sheikh Raisuddin (2004). Ayurvedic Bhasmas. In Scientific Basis for Ayurvedic Therapies. Mishra, L.C. Ed. CRC-Press- London. pp-83-100.

34. Singh, R.H. and Mishra, L.C. (2004). Psychiatric disorders. In Scientific Basis for Ayurvedic Therapies. Mishra, L.C. Ed. CRC-Press- London. pp-439-452.

35. Shaarangdhara, 'Shaarangdhara Samhitaa', (1983). Third edition. Prathama Khanda 1/53 Choukhambha Orientalia, Varanasi (India ). Page- 13.

36. Sushruta Samhitaa with Nibandh Sangraha commentary by Dalhana, edited by Jadavaji Trikamaji Aacaarya, (1992a). $5^{\text {th }}$ edition. Sutra Sthana- 1/32. Choukhamba Orientalia, Varanasi (India).

37. 36 . Sushruta Samhitaa with Nibandh Sangraha commentary by Dalhana, edited by Jadavaji Trikamaji Aacaarya, (1992b). $5^{\text {th }}$ edition. Sutra Sthana- 46/326-330 Choukhamba Orientalia, Varanasi (India).

38. Sushruta Samhitaa with Nibandh Sangraha commentary by Dalhana, edited by Jadavaji Trikamaji Aacaarya, (1992c). 5th edition. Choukhamba Orientalia, Varanasi (India). Page- 349.

39. Sushruta Samhitaa with Nibandh Sangraha commentary by Dalhana, edited by Jadavaji Trikamaji Aacaarya, (1992d). 5th edition, Choukhamba Orientalia, Varanasi (India). Page -164.

40. Sushruta Samhitaa with Nibandh Sangraha commentary by Dalhana, edited by Jadavaji Trikamaji Aacaarya, (1998)- Reprint. Cikitsaa Sthana10/11, 12/11 and 28/15,16, Krishnadaas Academy, Oriental Publishers \& Distributors, Vaaraanasi - 221001, India, (Sanskrit).

41. Vohora, D.S. and Mishra, L.C. ( 2004). Alzheimer's Disease. In Scientific Basis for Ayurvedic Therapies. Mishra, L.C. Ed. CRC-Press- London. pp-411-426 
42. Vaagbhata, Ashtaang Sangriha, with Commentary by Indu (1980). Edited by Anant Damodar Aathavale and Mahesh Anant Aathavale. Cikitsaa Sthana 12/32, 20-22, 24-26, and Uttara 35/24-26. Shrimad Atreya Prakashan, Pune 411,004 India.

43. Vaagbhata, Rasaratnasamuccaya, fifth edition (1976a). Chowkhamba Sanskrit Series Office, Varanasi (India).

44. Vaagbhata, Rasaratnasamuccaya, fifth edition (1976b), Chowkhamba Sanskrit Series Office, Varanasi (India), page137.

45. Vaagbhata, Rasaratnasamuccaya, 10/47, fifth edition (1976c), Chowkhamba Sanskrit Series Office, Varanasi (India).

46. Vaagbhata, 'Rasaratnasamuccaya'- 5/142, fifth edition (1976d), Chowkhamba Sanskrit Series Office, Varanasi (India).

47. Vaagbhata, Rasaratnasamuccaya, 5/13 fifth edition (1976e), Chowkhamba Sanskrit Series Office, Varanasi (India).

48. Vasudev Dvivedi, (1978). 'Paarad Vigyaaniya', Sharma Ayurved Mandir, Datya M.P. (India), pages 125, 193.

49. 48. Zahoor Ahmad Shah, Rabia Afzal Gilani, Pragya Sharma, Shashi Bharat Vohora (2005). Attenuation of Stress-Elicited Brain Catecholamines, Serotonin and Plasma Corticosterone Levels by Calcined Gold Preparations Used in Indian System of Medicine. Basic \& Clinical Pharmacology \& Toxicology 96 (6), 469-474.

50. http://www.reference.com/browse/zebrafish. Accessed on 29-05-2010.

51. http://www.ipapharma.org/pt/December2009/PharmaScene.pdf/Accessed on 12-3-2011. 